\title{
PENDIDIKAN RESPONSIF GENDER DI PROGRAM STUDI PENDIDIKAN TEKNIK ELEKTRONIKA FAKULTAS TEKNIK UNIVERSITAS NEGERI YOGYAKARTA
}

\section{GENDER RESPONSIVE EDUCATION IN ELECTRONIC ENGINEERING STUDY PROGRAM FACULTY OF ENGINEERING YOGYAKARTA STATE UNIVERSITY}

\author{
Setyo Atmiasih \\ Filsafat dan Sosiologi Pendidikan, Kebijakan Pendidikan FIP UNY \\ setyo.asih029@gmail.com.
}

\begin{abstract}
Abstrak
Penelitian ini bertujuan mengidentifikasi pelaksanaan pendidikan responsif gender di Program Studi Pendidikan Teknik Elektronika Fakultas Teknik Universitas Negeri Yogyakarta. Penelitian ini menggunakan metode pendekatan deskriptif kualitatif. Teknik yang digunakan dalam analisis data adalah kondensasi dan analisis gender, penyajian data, dan penarikan kesimpulan. Analisis gender digunakan untuk pembahasan tentang aktivitas, manfaat, akses, manfaat dan dampak pendidikan responsif gender. Uji keabsahan data menggunakan triangulasi sumber dan triangulasi teknik. Hasil penelitian menunjukkan bahwa : secara formal aktivitas pendidikan baik secara fasilitas, perlakuan pendidik, pelayanan administrasi, dan pembagain kelompok kerja telah responsif gender, tetapi secara individu masih terjadi bias gender karena adanya stereotipe terhadap laki-laki dan perempuan. Manfaat bagi para mahasiswa perempuan, mereka merasa percaya diri dapat mengerjakan tugas kuliah dan praktik yang selama ini dianggap bagian laki-laki. Perempuan dan laki-laki memiliki akses yang sama dalam kegiatan perkuliahan. Namun dalam struktur kemahasiswaan, seperti dalam kepemimpinan ketua kelas masih selalu dipercayakan kepada laki-laki, sedangkan perempuan menjadi bendahara dan sekretaris dalam hal ini masih terlihat ada bias gender. Adanya bias gender dalam pendidikan menyebabkan turunnya minat mahasiswa, sehingga berdampak terhadap hasil belajar mahasiswa dan interaksi yang kurang harmonis antara laki-laki dan perempuan.
\end{abstract}

Kata Kunci : Pendidikan Responsif Gender, Perempuan, Kesetaraan

\begin{abstract}
This study aims to identify the implementation of gender responsive education in the Electronic Engineering Education Study Program, Faculty of Engineering, Yogyakarta State University. This research uses a descriptive qualitative approach. Techniques used in data analysis are condensation and gender analysis, data presentation, and conclusion drawing. Gender analysis is used for discussion of activities, benefits, access, benefits and impacts of gender responsive education. Test the validity of the data using source triangulation and technique triangulation.The results of his research: formally educational activities both in terms of facilities, educator treatment, administrative services, and the division of work groups have been gender responsive, but individually gender bias still occurs because of the stereotypes of men and women. Benefits for female students, they feel confident that they can work on college assignments and practices that so far have been considered male. Women and men have equal access to lecture activities. But in the student structure, such as in the leadership of the class leader is always entrusted to men, while women become treasurers and secretaries in this case there still seems to be a gender bias. The existence of gender bias in education causes a decrease in student interest, thus impacting student learning outcomes and interactions that are less harmonious between men and women.
\end{abstract}

Keywords: Gender Responsive Education, Women, Equality 


\section{PENDAHULUAN}

Undang-undang No. 20 Tahun 2003 tentang sistem pendidikan nasional menyatakan bahwa pendidikan diselenggarakan secara demokratis dan berkeadilan serta tidakdiskriminatif dengan menjunjung tinggi hak asasi manusia, nilai keagamaan nilai kultural dan kemajemukan bangsa yang berarti bahwa pendidikan di Indonesia harus diselenggarakan secara adil, tidak diskriminatif, dan memperhatikan keberagaman. Keadilan harus menjadi acuan utama pembangunan dalam segala hal di Indonesia termasuk dalam bidang pendidikan. Salah satu bentuk keadilan adalah adanya kesetaraan antara laki-laki dan perempuan didalam segala proses pendidikan yang diselenggarakan oleh suatu institusi pendidikan, termasuk di tingkat perguruan tinggi sebagai jenjang pendidikan tertinggi yang seharusnya dalam penyelenggaraannya dilakukan sebaik mungkin. Kesetaraan antara lakilaki dan perempuan merupakan salah satu dari hak asasi manusia. Hak asasi manusia menjadi hak dasar yang melekat pada manusia secara kodrati sebagai anugerah Tuhan Yang Maha Esa yang harus dihormati, dilindungi, dan tidak layak untuk dirampas oleh siapapun. Dasar pilar utama HAM adalah persamaan, kebebasan atau kemerdekaan dan keadilan. Hasil dari Universal Declaration of Human Rights tahun 1984 menyatakan bahwa manusia dilahirkan sama dan setara di dalam harkat dan haknya. Persamaan hak yang terkandung dalam deklarasi tersebut bahwa tidak ada perbedaan antara ras maupun gender.

Bertolak dari isi pernyataan dalam dokumen tersebut dalam kenyataannya perbedaan-perbedaan dalam masyarakat umat manusia masih saja muncul berbagai jenis diskriminasi berdasarkan ras, agama, kedudukan ekonomi, kedudukan sosial dan perbedaan gender dalam berbagai bidang, termasuk dalam bidang pendidikan, yang dapat dilhat dari laporan data Gender Development Index (GDI) dari United Nation Development Profrgramme (2016:217) menyatakan bahwa pada tahun 2018 angka GDI di Indonesia adalah 0.932. Angka tersebut masih tertinggal dari Filipina yang mencapai 1.000 dan Vietnam yang menunjukkan nilai lebih tinggi yaitu 1.005. Salah satu indikator penilaian GDI adalah pendidikan responsif gender yang ada pada negara tersebut. Dapat dikatakan bahwa jika nilai GDI semakin tinggi maka pendidikan responsif gender dalam negara tersebut semakin baik, begitu juga sebaliknya. Gender Development Index dapat menjadi tolok ukur keberhasilan pendidikan dalam mensosialisasikan kesetaraan dan keadilan gender di Indonesia.

Praktik diskriminasi dalam pendidikan bentuknya bermacammacam, antara lain kekerasan fisik maupun psikis, stigma negatif, dan marginalisasi. Contoh bias gender dalam pendidikan dapat dilhat dari minimnya partisipasi perempuan dalam memilih dan masuk kedalam program studi di perguruan tinggi. Pengaruh budaya patriarkhi yang menempatkan perempuan sebagai pengurus dan penanggung jawab dalam pekerjaan domestik. Dapur dan garasi memiliki konotasi gender yang kuat. Dapur ruang untuk mengolah makanan sangat kuat asosiasinya dengan aktivitas feminim, sementara garasi ruang untuk menyimpan kendaraan dengan aktivitas yang lebih maskulin (Abdullah, 1997:145). Persepsi ini memunculkan 
stereotipe dalam masyarakat luas terhadap beberapa jurusan yang sangat kental dengan identitas gender, misalnya adanya pelabelan bahwa Jurusan Teknik Mesin untuk laki-laki sebab hal-hal yang bersinggungan dengan mesin menunjukkan sifat maskulin, sama halnya dengan Program Studi Pendidikan Teknik Elektronika yang melakukan berbagai kegiatan di dalam bengkel yang digunakan untuk mengerjakan berbagai kegiatan yang menunjukkan sifat maskulin yang biasa dikerjakan oleh lakilaki seperti pemotongan besi, pengeboran dan penyolderan sedangkan Jurusan Tata Boga untuk perempuan, sebab di Jurusan Tata Boga mengajarkan hal-hal yang berkaitan dengan dapur.

Seiring dengan perkembangan yang ada di dalam masyarakat yang memperjuangkan kesetaraan gender, beberapa peran yang dilekatkan pada lakilaki dan perempuan telah dipertukarkan. Hal ini menjadi dapat dibuktikan dengan cukup banyaknya kaum perempuan yang memasuki area maskulinitas dan berani tampil di sektor publik. Tidak jarang pula kaum pria yang ikut mengerjakan tugas perempuan di sektor domestik. Sejalan dengan pengarustamaan gender, telah ada perempuan yang mendalami ilmu elektronika dengan menjadi mahasiswa Program Studi Pendidikan Teknik Elektronika meskipun perempuan merupakan kelompok minoritas dari total keseluruhan mahasiswa di program studi tersebut. Data jumlah mahasiswa aktif persemester genap pada tahun 2019 yang tercantum pada web resmi Program Studi Pendidikan Teknik Elektronika menunjukkan bahwa jumlah mahasiswa pada Program Studi Pendidikan Teknik Elektronika terdapat 156 mahasiswa yang terdiri dari 41 mahasiswa perempuan dan 115 mahasiswa laki-laki.

Mengurangi diskriminasi gender dalam

lembaga pendidikan dapat diminimalisir dengan adanya edukasi tentang kesetaraan dan keadilan gender. Edukasi tersebut harus dilakukan di mana saja, termasuk dalam kegiatan pembelajaran di dalam kelas maupun di luar kelas hingga kegiatan sehari-hari agar menjadi sebuah kebiasaan yang menciptakan kultur responsif gender. Invensi pemerintah untuk merumuskan kebijakan, program, dan kegiatan yang responsif gender juga perlu dilakukan. Menurut Astutiningsih dalam Roziqoh dan Suparno (2014:89) upaya menciptakan kesetaraan gender dan keadilan gender dalam lembaga pendidikan, dapat dilakukan dengan beberapa cara yaitu : (1) sistem pendidikan yang sensitif terhadap gender agar terdapat akses yang sama dalam pendidikan dan pelatihan, (2) menghapus disparitas dalam memperoleh akses pendidikan, serta (3) memperbaiki mutu pendidikan dan meningkatkan kesempatan terhadap perempuan memperoleh pengetahuan, keterampilan sehingga dapat mewujudkan kesetaraan gender dan keadilan gender.

Negara Indonesia memiliki landasan yang dapat dijadikan acuan dalam mewujudkan kesetaraan dan keadilan gender. Landasan tersebut tercantum dalam instruksi presiden Nomor 9 Tahun 2000 menginstruksikan kepada seluruh kementrian, lembaga pemerintah non departemen, Pimpinan Kesekretariatan Lembaga Tertinggi/Tinggi negara, panglima TNI, Kepolisian Republik Indonesia, Kejaksaan Agung dan Gubernur serta 
Bupati/Walikota untuk mengarustamakan gender dalam berbagai aspek kegiatan pembangunan. Pengarustamaan gender dibidang pendidikan yaitu kebijakan PUG ditindak lanjuti dengan dikeluarkannya peraturan menteri Pendidikan Nasional Nomor 84 Tahun 2008 tentang pedoman pelaksanaan PUG di bidang pendidikan. Di dalam Permendiknas Nomor 84 tersebut mengatur bahwa setiap satuan unit kerja di bidang pendidikan yang merencanakan, pelaksanaan, pemantauan dan program pembangunan agar mengintegrasikan gender di dalamnya. Regulasi di atas diharapkan dapat membuat paradigma baru yang lebih memberikan kesempatan seluas-luasnya bagi laki-laki dan perempuan untuk berpartisipasi dalam pendidikan.

\section{Dengan banyaknya jumlah} mahasiswa laki-laki dari pada mahasiswa perempuan di Program Studi Pendidikan Teknik Elektronika, mendukung besarnya potensi adanya ketidaksetaraan gender dalam menjalankan praktik pendidikan. Perempuan masih distereotipkan tidak memiliki kemampuan dalam mengerjakan pekerjaan maskulin. Peneliti ingin melihat bagaimana pelaksanaan pendidikan responsif gender di Program Studi Pendidikan Teknik Elektronika Fakultas Teknik Universitas Negeri Yogyakarta.

\section{METODE PENELITIAN}

\section{Jenis Penelitian}

Penelitian ini merupakan penelitian kualitatif dengan pendekatan deskriptif, yang disesuaikan dengan tujuan penelitian ini yaitu untuk mengetahui mengetahui bagaimana pelaksanaan pendidikan responsif gender di Program Studi Teknik Elektronika Fakultas Teknik Universitas Negeri Yogyakarta. Bogdan dalam Moleong (2014:5) mendefinisikan bahwa metodelogi kualitatif sebagai prosedur penelitian yang menghasilkan data deskriptif berupa kata- kata tertulis atau lisan dari orang-orang dan perilaku yang dapat diamati.

\section{Waktu dan Tempat Penelitian}

Penelitian dilaksanakan pada bulan April

- Juni 2019. Penelitian ini mengambil lokasi di Program Studi Teknik Elektronika Fakultas Teknik Universitas Negeri Yogyakarta yang terletak di Jalan Colombo No. 1, Karang Malang, Kelurahan Caturtunggal, Kecamatan Depok, Kabupaten Sleman, Provinsi Daerah Istimewa Yogyakarta.

\section{Subjek dan Obyek Penelitian}

Subjek penelitian ini adalah FA (Ketua Program Studi), SAD (Dosen Laki-laki), BW (Dosen Perempuan), (FA) Karyawan Laki-laki, VW (Karyawan Perempuan) dan AG (Mahasiswa Lakilaki) serta NR, ES (Mahasiswa Perempuan). Selain itu, juga dilakukan pencarian data terkait jumlah mahasiswa, pendidik dan karyawan laki- laki dan perempuan serta prestasi yang dirah oleh mahasiswa laki-laki dan perempuan melalui data yang diberikan oleh staff bagian admin dan laman web resmi Program Studi Pendidikan Teknik Elektronika Fakultas Teknik Universitas Negeri Yogyakarta.

\section{Teknik Pengumpulan Data}

Pengumpulan data dalam penelitian 
ini menggunakan teknik observasi non partisipan, wawancara semi terstruktur dan studi dokumentasi.

\section{Teknik Analisis Data}

Teknik analisis data yang digunakan adalah Miles, Huberman dan Saldana dalam Armando (2017: 47) yaitu menganalisis data dengan tiga langkah: kondensasi data (data condensation), penyajian data (data display), dan menarik simpulan atau verifikasi (conclusion drawing and verification) dan Hanum (2018:15) yaitu analisis aktivitas, analisis manfaat, analisis akses, analisis kontrol dan analisis dampak.

\section{Teknik Keabsahan Data}

Uji keabsahan data dalam penelitian ini menggunakan uji kredibilitas dengan melakukan triangulasi yaitu untuk menguji kredibilitas data yang dilakukan dengan cara mengecek data yang telah diperoleh melalui beberapa sumber dan juga menggunakan triangulasi teknik yaitu untuk menguji kredibilitas data yang dilakukan dengan cara mengecek data kepada sumber yang sama dengan teknik yang berbeda.

\section{HASIL PENELITIAN DAN PEMBAHASAN}

Aktivitas pendidikan di Program Studi Pendidikan Teknik Elektronika tidak memiliki kebijakan khusus dalam pelaksanaan pendidikan responsif gender yang dimasukkan kedalam kurikulum pembelajaran, namun berupaya memasukkan unsur-unsur pendidikan responsif gender melalui berbagai upaya yaitu memberikan perhatian yang seimbang bagi mahasiswa laki- laki dan mahasiwa perempuan dalam proses pembelajarannya dan penggunaan bahasa yang responsif gender, upaya lainnya adalah berusaha memberikan akses yang sama kepada mahasiswa laki-laki maupun perempuan melalui pemenuhan akses sarana dan prasarana yang digunakan untuk proses pembelajaran serta adanya interaksi diantara kedua jenis kelamin, interaksi pada saat proses pembelajaran antara mahasiswa laki-laki dan perempuan terjalin dengan baik disaat pembelajaran dalam kelas maupun luar kelas hingga pemberian pelayanan akademik yang adil bagi seluruh mahasiswa. Secara formal sarana prasarana dan aktivitas yang ada di Program Studi Pendidikan Teknik Elektronika Fakultas Teknik Universitas Negeri Yogyakarta tidak membedakan laki-laki dan perempuan, tetapi secara individual masih terjadi bias gender 
karena adanya stereotipe bahwa adanya anggapan tertentu kepada salah satu jenis kelamin.

Peran pendidik dan lembaga pendidikan terkait sangat penting untuk meminimalkan tindakan bias gender pada aktivitas pembelajaran yang menimbulkan ketidakadilan bagi salah satu jenis kelamin, perlunya membudayakan budaya saling menghargai dan menghormati diantara kedua jenis kelamin perlu ditanamkan kepada seluruh mahasiswa, pendidik dan pegawai yang bertugas demi terciptanya lingkungan belajar yang responsif gender.

Manfaat dari masuknya perempuan dalam sektor maskulin bagi perempuan yaitu dapat membantu perempuan untuk memperoleh pengetahuan dan keterampilan lebih yang dapat membantunya dalam kehidupan sehari-hari bahkan dapat bermanfaat bagi orang lain. Adanya pendidikan responsof gender juga menumbuhkan rasa saling menghargai diatara kedua jenis kelamin, khususnya terhadap perempuan serta perubahan pandangan masyarakat terhadap perempuanpun ikut berubah yang mengangkat derajat perempuan menjadi lebih baik dan merubah pandangan terhadap laki-laki yang dianggap sebagai manusia yang pemalas.

Program Studi Pendidikan Teknik Elektronika Fakultas Teknik Universitas Negeri Yogyakarta memberikan akses penuh bagi laki- laki mupun perempuan dalam pemanfaatan sarana dan prasarana yang ada yaitu berupa alat-alat praktik, dan berbaga fasilitas lannya. Namun, belum mampu mengaplikasikan sikap prinsip gender dalam proses penyelenggaraan pendidikan, dikarenakan masih kentalnya budaya patriarkhi, sebab perempuan masih dianggap lebih lemah dari pada laki-laki.

Masih adanya ketidaksetaraan dan ketidakadilan bagi perempuan untuk menjadi pemimpin, jumlah laki-laki yang lebih banyak daripada perempuan juga turut menjadi sebab dominasi peran lakilaki dalam proses pengendalian kelas hingga dalam pengambilan sebuah keputusan. Keseimbangan peran laki-laki dan perempuan dalam segala proses pengambilan keputusan haruslah seimbang, agar terciptanya kesetaraan dan keadilan gender bagi kaum minoritas.

Program Studi Pendidikan Teknik Elektronika Fakultas Teknik Universitas Negeri Yogyakarta untuk saat ini belum dapat memenuhi indikator pendidikan kesetaraan gender, dikarenakan masih adanya penggunaan bahasa yang bias gender hingga menyebabkan salah satu jenis kelamin menjadi terintimidasi dan masih kurangnya rasa percaya diri serta rasa malu di dalam diri mahasiswa perempuan sebagai mahasiswa minoritas yang mempengaruhi kesempatan dan peran perempuan untuk ikut dalam perumusan kebijakan dan pengambilan keputusan, ditambah dengan adanya oknum pendidik yang memberikan perhatian perhatian lebih pada salah satu jenis kelamin saja menimbulkan kecemburuan sosial dan rasa ketidakadilan yang ada diantara mahasiswa. Lalu belum tersedianya data terpilah berdasarkan jenis kelamin sebagai dasar informasi dalam gender dalam penyajian data mahasiswa dan pendidik serta pegawai, sehingga peneliti harus memilah data yang ada. 


\section{Pembahasan}

Aktivitas pembelajaran di Program Studi Pendidikan Teknik Elektronika Fakultas Teknik Universitas Negeri Yogyakarta sudah ada di situasi pembelajaran yang responsif gender dengan berusaha untuk memberikan perhatian yang seimbang bagi mahasiswa laki-laki dan mahasiswa perempuan dalam segala proses pembelajaran pendidikan. Pendidik di Program Studi Pendidikan Teknik Elektronika Fakultas Negeri Yogyakarta telah berupaya untuk memberikan perhatian yang seimbang bagi mahasiswa laki-laki dan mahasiswa perempuan melalui banyak hal, seperti memberikan respon yang adil bagi mahasiswa yang mengajukan pertanyaan ataupun menyampaikan pendapat, lalu memberikan bantuan kepada mahasiswa yang mengalami kesulitan dalam proses pembelajaran berlangsung, membagi beberapa kelompok bukan berdasarkan jenis kelamin, dan mencoba untuk tidak mengeneralisir dengan memberikan label tertentu yang bersifat diskriminatif kepada salah satu jenis kelamin hingga membuka sesi tanya jawab yang berlaku untuk seluruh mahasiswa. Sesi tanya jawab tersebut tidak hanya dapat mendorong akses dan partisipasi mahasiswa perempuan yang jumlahnya lebih sedikit dari mahasiswa laki-laki untuk menyuarakan pendapat dan bertanya, namun juga menumbuhkan interaksi yang baik diantara mahasiswa laki-laki dan perempuan selama proses pembelajaran berlangsung.

Selain usaha untuk memberikan perhatian yang seimbang bagi mahasiswa laki-laki dan mahasiswa perempuan, penataan kelas yang merespon kebutuhan mahasiswa laki-laki dan perempuan yang tentunya tidak mengandung unsur bias gender di dalamnya juga sudah dilakukan oleh Program Studi Pendidikan Teknik Elektronika FT UNY dengan melengkapi fasilitas sarana pembelajaran yang berupa ruang kelas, alat-alat praktik serta berbagai fasilitas umum yang dapat digunakan oleh seluruh mahasiswa. Fasilitas umum tidak terlepas dari berbagai pajangan dan tempelan dinding yang bertujuan untuk menyampaikan pesan bagi setiap orang yang membacanya, salah satunya adalah poster berupa ucapan selamat bagi mahasiswa yang meraih prestasi dalam berbagai perlombaan adalah salah satu bentuk apresiasi dari prodi bagi mahasiswa lakilaki dan mahasiswa perempuan. Lalu adanya berbagai papan peringatan yang berisi berbagai tata tertib hingga petunjuk penggunaan suatu alat yang ramah gender dalam kegiatan praktikum yang ada di Program Studi Pendidikan Teknik Elekktronika sangatlah penting bagi keselamatan selama pembelajaran berlangsung.

Penggunaan bahasa yang responsif gender adalah aspek penting dalam mewujudkan terciptanya pendidikan yang responsif gender. Penggunaan bagasa yang responsif gender diterapkan dalam segala kegiatan proses pembelajaran seperti yang dikemukakan oleh Wibowo (2010:193) bahasa juga dapat mendorong terjadinya ketidaksetaraan. Sebagai contoh, bahasa yang digunakan dikelas seringkali merefleksikan dominasi peserta didik laki-laki di kelas dan melemahkan perempuan untuk memiliki posisi lebih rendah. Guru merefleksikan bias gender yang dimilikinya melalui bahasa yang sesuai kepercayaannya bahwa laki-laki tidak sepandai dan setekun perempuan, 
dan perempuan tidak seberani laki-laki dan sebagainya.

Pada Program Studi Pendidikan Teknik Elektronika Fakultas Teknik Universitas Negeri Yogyakarta masih adanya penggunaan bahasa yang bias gender yang terjadi di dalam proses pembelajarannya yang dilakukan oleh salah satu pendidik saat proses kegiatan belajar mengajar berlangsung. Pendidik yang seharusnya menjadi teladan bagi peserta didik tidak seharusnya melakukan hal tersebut, tak hanya antara mahasiswa dengan pendidik saja, namun diantara mahasiswa laki-laki dan perempuan. Penggunaan bahasa yang bias gender seperti yang dilakukan yang diterima salah satu jenis kelamin terjadi beberapa kali akan menimbulkan sebuah kebiasaan dan serta interaksi yang buruk yang nantinya akan menjadi suatu budaya yang tidak baik diantara laki-laki dan perempuan.

Penyelenggaraan pendidikan yang responsif gender memberikan manfaat bagi mahasiswa laki-laki dan perempuan yang memberikan pandangan bahwa adanya kesempatan yang sama bagi laki-laki dan perempuan untuk ikut andil dalam proses pembentukan dan pengambilan kebijakan yang masuk dalam kontrol pendidikan yang ada di Program Studi Pendidikan Teknik Elektronika Universitas Negeri Yogyakarta. Adanya partisipasi dan peran perempuan dalam penyelenggaraan pendidikan di tempat yang dipandang maskulin memberikan manfaat lebih bagi perempuan di kehidupan sehari-hari yang dapat meningkatkan keterampilan dan pengetahuannya serta menunjukkan bahwa perempuan dapat melakukan halhal yang bersifat maskulin.

Program Studi Pendidikan Teknik
Elektronika Fakultas Teknik Universitas Negeri Yogyakarta memiliki jumlah pendidik laki-laki yang lebih banyak daripada jumlah pendidik perempuan, sama halnya dengan jumlah mahasiswa yang ada di prodi tersebut. Setiap tahunnya, hanya ada beberapa mahasiswa perempuan yang mengenyam pendidikan disana. Jumlah laki-laki yang dominan menjadikan laki- laki mendapat ruang lebih besar untuk menduduki posisi pemimpin dalam proses penyelenggaraan pendidikan beserta pengambilan keputusan. Seperti posisi ketua kelas yang berturut-turut di duduki oleh mahasiswa laki-laki, sedangkan mahasiswa perempuan hanya di tempatkan pada posisi-posisi dibawahnya. Pemilihan ketua kelas beserta pengurus kelas mulai dari sekertaris dan bendahara dipilih secara voting yang seharusnya dapat membuka peluang perempuan menjadi pemimpin ternyata tetap membuat keberadaan mahasiswa perempuan dianggap kurang penting. Keseimbangan peran laki-laki dan perempuan dalam segala proses pengambilan keputusan haruslah sama, agar terciptanya kesetaraan dan keadilan gender bagi kaum minoritas yang akan berpengaruh pada hasil belajar mahasiswa laki- laki maupun mahasiswa perempuan dan hubungan yang kurang baik diantara mahasiswa laki-laki dan mahasiswa perempuan. Dengan adanya penyelenggaraan pendidikan yang responsif gender terciptanya interaksi yang lebih baik diantara mahasiswa laki-laki dan mahasiswa perempuan serta terbentuknya lingkungan belajar yang lebih baik.

\section{SIMPULAN DAN SARAN Simpulan}

Pelaksanaan pendidikan responsif 
gender di Program Studi Pendidikan Teknik Elektronika Fakultas Teknik Universitas Negeri telah mengupayakan untuk menyelenggarakan pendidikan yang responsif gender kepada seluruh mahasiswanya, baik berupa pemenuhan fasilitas sarana dan prasarana hingga bagaimana pendidik mengontrol agar tetap berjalan dengan berusaha agar mengutamakan keadilan dan kesetaraan gender dalam kegiatan pembelajarannya yang patut diapresiasi. Secara formal, fasilitas yang diberikan kepada mahasiswa dan aktivitas pembelajaran tidak membedakan laki-laki dan perempuan, tetapi secara individual masih terjadinya bias gender yang dikarenakan oleh stereotipe bahwa laki-laki lebih pemalas dari perempuan hingga perempuan adalah makhluk yang lemah.

Dengan adanya pendidikan responsif gender dalam program studi yang masih dianggap maskulin oleh masyarakat luas, dikarenakan mengandung aktivitas-aktivitas pembelajaran yang identik dengan lakilaki seperti pengeboran, penyolderan hingga membuat kerangka robot tidak membuat perempuan untuk masuk kedalam ranah tersebut, bahkan dalam praktiknya perempuan mendapat manfaat dari adanya kegiatan tersebut yang berguna bagi kegiatan sehari-hari dan dapat menggunakan ilmunya untuk membantu orang lain hingga di masa mendatang yang dapat meningkatkan pengetahuan, keterampilannya dan dapat merubah pandangan masyarakat terhadap perempuan bahwa perempuan tidak dapat mengerjakan pekerjaan yang masuk dalam kegiatan yang maskulin yang sering dikerjakan oleh kaum laki- laki serta menumbuhkan interaksi yang lebih baik diantara kedua jenis kelamin.

Saran Program Studi Pendidikan Teknik Elektronika Fakultas Teknik
Universitas Negeri Yogyakarta memberikan akses penuh bagi laki- laki mupun perempuan dalam pemanfaatan sarana dan prasarana yang ada yaitu berupa alat-alat praktik, dan berbagai fasilitas lainnya. Namun, Program Studi Pendidikan Teknik Elektronika Fakultas Teknik Universitas Negeri Yogyakarta belum mampu mengaplikasikan pripsip kesetaraan gender dalam proses penyelenggaraan pendidikan, dikarenakan masih kentalnya budaya patriarkhi, sebab perempuan masih dianggap lebih lemah dari pada laki-laki.

Jumlah pendidik laki-laki yang lebih banyak daripada jumlah pendidik perempuan, sama halnya dengan jumlah mahasiswa yang ada di prodi tersebut. Setiap tahunnya, hanya ada beberapa mahasiswa perempuan yang mengenyam pendidikan disana. Jumlah laki-laki yang dominan menjadikan laki-laki mendapat ruang lebih besar untuk menduduki posisi dan mengambil keputusan penting dalam proses penyelenggaraan pendidikan beserta pengambilan keputusan. Seperti posisi ketua kelas yang berturut-turut di duduki oleh mahasiswa laki-laki, sedangkan mahasiswa perempuan hanya di tempatkan pada posisi-posisi dibawahnya. Pemberian kesempatan yang sama bagi setiap mahasiswa untuk mengisi posisi penting tersebut tidak membuat perempuan mengajukan diri sebagai pemimpin, hal ini didasari oleh adanya rasa kurang percaya diri dari dalam diri perempuan yang ragu akan kemampuannya, tak hanya itu visualisasi laki-laki yang dianggap lebih tegas, logis dan bertanggung jawab ikut menjadi faktornya.

Jumlah perempuan yang lebih sedikit

daripada laki-laki ikut serta menjadi faktor terjadinya berbagai peristiwa yang bias gender yang dapat mengakibatkan mahasiswa perempuan dinomorduakan, 
tak hanya mahasiswa perempuan saja yang mendapatkan tindakan yang diskriminatif, bahkan mahasiswa laki-laki mendapatkan label yang negatif dari seorang pendidik, hal ini dapat berakibat buruk bagi mahasiswa baik mahasiswa laki-laki maupun perempuan yang membuat menurunnya minat mahasiswa dalam mata kuliah dengan pendidik yang bersangkutan hingga berdampak pada hasil belajar mahasiswa dan hubungan yang kurang harmonis diantara kedua jenis kelamin. Dengan adanya penyelenggaraan pendidikan yang responsif gender terciptanya interaksi yang lebih baik diantara mahasiswa lakilaki dan mahasiswa perempuan serta terbentuknya lingkungan belajar yang lebih harmonis.

\section{Saran}

Diharapkan agar pendidik dan mahasiswa laki-laki maupun perempuan yang ada di Program Studi Pendidikan Teknik Elektronika Fakultas Teknik Universitas Negeri Yogyakarta lebih memperluas lagi wawasan mengenai pendidikan responsif gender.

\section{DAFTAR PUSTAKA}

Amin Abdullah. (2004). Kesetaraan Gender di Perguruan Tinggi Islam. Yogyakarta: Kerjasama UIN Sunan Kalijaga Yogyakarta dengan McGill-IAIN- Indonesia Social Equity Project.

Armando, Jerry. (2017). Transitivitas Dan Konteks Situasi Teks Bacaan Buku Bahasa Inggris Kelas X. Tesis. Medan: Fakultas Ilmu Budaya Universitas Sumatra Utara

Debdikbud. (2003). Undang-Undang RI Nomor 20, Tahun 2003, Tentang Sistem Pendidikan Nasional.

Depdiknas. (2008) Panduan Sekolah

Berwawasan Gender. Jakarta : Depdiknas
Faisal, N. (2018). Implementasi Program Sekolah Responsif Gender Di SMP Negeri 15 Yogyakarta.Skripsi. FIS UNY

Muawana, E. (2009). Pendidikan Gender dan Hak Asasi Manusia. Yogyakarta: Penerbit Teras.

Fakih, M. (1996). Menggeser Konsepsi Gender dan Transformasi Sosial. Yogyakarta: Pustaka Pelajar.

Hanum, F. (2018). Kajian dan Dinamika Gender.

Malang: Intrans Publishing.

Hidir, A., Meilani, L. N., \& Tua, H. T. R. S. (2016). Pendidikan Responsif Gender Di Kabupaten Rokan Hilir.Jurnal. 5. 05.214231.

Human Development Reports. (2016).

Gender Development Index. New

York: United Nations

Development Programme.

Diakses pada tanggal 2 Februari

2019 dari

http://hdr.undp.org/en/countries/p rofiles/I DN.

Irawan, Z. D. (2009). Besarnya Eksploitasi Perempuan dan Lingkungan Di Indonesia. Jakarta: Elex Media Komputindo.

Intruksi Presiden No. 9 Tahun 2000, Tentang Pengarustamaan Gender dalam Pembangunan Nasional. Diakses pada tanggal pada 2 Februari 2019 dari https://www.kemenkeu.go.id/sites /default/ files/inpres-no.-9-tahun2000-tentang- pug.pdf.

Pratiwi, K. (2017). Pemenuhan Standar Manajemen Sekolah Responsif Gender Di Kabupaten Sragen.Skripsi. FISIPOL UNS.

Moleong, Lexy J. (2005). Metedologi Penelitian Kualitatif. Bandung: PT Remaja Rosdakarya.

Nawal Al'Sa'dawi dan Hibah Rauf Izzat. (2000). Perempuan, Agama dan Moralitas, Antara Nalar Feminis dan Islam Revivalis. Jakarta: Erlangga. 
Sugiyono. (2010). Memahami Penelitian

Kualitatif. Bandung: ALFABETA

Tim Website UNY (2018). Daftar

Prestasi Mahasiswa

Program Studi

Pendidikan

Elektronika Tahun Ajaran

2016-2018. Yogyakarta.

UNY. Yang diakses pada

tanggal $20 \quad$ Juli 2019

dari

http://pendidikan-teknik-

elektronika.ft.uny.ac.id/prestasi.

Tim Website UNY (2019) Daftar Dosen

dan Staff Program Studi

Pendidikan Elektronika.

Yogyakarta UNY. Yang diakses

pada tanggal 20 Juli 2019 dari

http://staff.uny.ac.id/category/juru

san- ft/pendidikan-teknik-

elektronika.

Tim Redaksi. (2008). Kamus Besar Bahasa

Indonesia (Edisi Keempat).

Jakarta: PT Gramedia Pustaka

Utama. 